\title{
KRT19 wt Allele
}

National Cancer Institute

\section{Source}

National Cancer Institute. KRT19 wt Allele. NCI Thesaurus. Code C52439.

Human KRT 19 wild-type allele is located in the vicinity of $17 q 21.2$ and is approximately 5 kb in length. This allele, which encodes keratin, type I cytoskeletal 19 protein, plays a role in muscle fiber organization. 